\title{
Antimicrobial activity of the leaf of the white species of Sesamum indicum from Benue State, Nigeria
}

\author{
C.E. OGWUCHE ${ }^{1 *}$, J.O. AMUPITAN ${ }^{2}$ and G.I. NDUKWE ${ }^{2}$ \\ ${ }^{I}$ Department of Chemistry, Federal University of Petroleum Resources Effurun, Nigeria. \\ ${ }^{2}$ Department of Chemistry, Ahmadu Bello University Zaria, Kaduna State, Nigeria. \\ *Corresponding author; E-mail: christogwu@gmail.com, Tel: +2347037166612
}

\begin{abstract}
This study investigates the antimicrobial activity of the leaf of the white specie of Sesamum indicum from the region of Benue State, Nigeria. The leaf of the plant was air dried under shade, segregated and pulverized. $840.56 \mathrm{~g}$ of the pulverized plant materials were carefully weighed and loaded into a Soxhlet extractor. It was extracted successively using petroleum spirit, ethyl acetate and methanol. The leaf extracts were investigated for in vitro antimicrobial activity against some organisms and their chemical constituents were also ascertained. The preliminary phytochemical screening of the various extracts showed the presence of carbohydrate, saponnins, triterpenes, steroids, tannins, flavonoids, and cardiac glycosides. The antimicrobial activity of these crude extracts showed activity on the organisms Staphylococcus aureus, Streptococcus pyogenes, Salmonella Typhi, Candida albicans, Candida krusei, and Candida tropicalis at various MIC's and (MBC/MFC)'s. All the crude extracts were inactive against the organisms Bacillus cereus, Corynebacterium ulcerans, and Escherichia coli.
\end{abstract}

(C) 2015 International Formulae Group. All rights reserved.

Keywords: Anti-microbial, Benue, pathogenic micro-organisms, Sesamum indicum leaves.

\section{INTRODUCTION}

Plant ecology has been studied formally and consistently since the beginning of human race. It has long been known that certain plants contain "principles" which exert marked physiological effects on the central nervous systems of animals (Nascimento et al., 2000). According to the nature and advancement of the particular human society, these plants and their products have been variously regarded as natural products. Several Nigerian plant extracts have been known with microbial activities (Adeleye et al., 2008; Ibrahim et al., 2005). Medicinal plants may never be completely understood by analyzing their component parts. Proponents of medicinal plants argue that their properties come from the interactions of multiple constituents (Kliger, 2004; Thoison et al., 2004). These interactions are known to some as chemical synergy.

Natural medicines have been used for centuries in many parts of Asia, such as China and India. In particular, native Americans had a profound impudence on the natural medicines of today Odumodu (1992). For centuries, such people passed on this knowledge from generation to generation, 
making use of available techniques to obtain the plant extracts.

Antimicrobial activity has formed basis of many applications, including pharmaceutical, row and processed food preservations, alternative medicine and natural therapies. This aspect assumes a particular relevance due to an increased resistance of some bacteria strains to the most common antibiotics and antimicrobial agents for food preservation (Grainger, 2001; Bruneton, 2009).

The study of botany as regards plants in the area of medicine today is recognised as the most viable method of identifying new medicinal plants or refocusing on those earlier reports of bioactive constituents (Adjanohoun et al., 1991; Farnsworth, 1996). It is against this background that the leaves of Sesamum indicum, which is one of the plants that is extensively used as a herbal preparation in some parts of Nigeria, are investigated. The plant leaf is found to be of medicinal importance among traditional medicine practitioners across Africa Cohen (1992) and Gill (1992).

The Nei Ching is one of the earliest health science anthologist ever produced and dates back to the thirtieth century BC (Nakanishi, 1999). Some of the first records on the use of natural product in medicine were written in cuneiform in Mesopotamia on day tablets and date to approximately 2600 BC (Cragg and Newman, 2001). Indeed, many of these agents continue to exist in one form or another to this day as treatment for inflammation, influenza, coughing and parasitic infestation. Chinese herbs guides document the use of herbaceous plants as far back in time as 2000 BC (Holt and Chandra, 2002).

\section{MATERIALS AND METHODS}

The plant Sesamum indicum leaves were collected from Makurdi, Benue State in the month of August, 2010. They were properly identified at the herbarium,
Department of Biological Sciences, Ahmadu Bello University, Zaria, Nigeria. The voucher specimen number was indicated. Thereafter, the leaves were dried for two weeks in the laboratory in readiness for the experiment.

\section{Extraction and fractionation}

The classical procedure for obtaining organic constituents from dried plant tissue by Harbone (1997) and Sofowora (2008) was used. This method involves the use of a Soxhlet apparatus and a range of solvents. Each extraction process was exhaustive using petroleum spirit $\left(60-80{ }^{\circ} \mathrm{C}\right)$, followed by chloroform, ethyl acetate and methanol and finally concentrated under reduced pressure. $856 \mathrm{~g}$ portion of the coarse powdered leaf material was packed into a soxhlet extractor thimble and was operated at a temperature of $80{ }^{\circ} \mathrm{C}$. The extracts were evaporated using a rotary evaporator under reduced pressure and kept in a desiccator.

\section{Phytochemical analysis}

The different crude solvent extracts obtained by the successive extractions from the soxhlet extractor were all subjected to phytochemical screening using standard techniques of plant secondary metabolites by Harborne (1997), Sofowora (2008) and Trease and Evans (2009). The crude plant extract was tested for alkaloids, saponins, glycosides, phlobotannins, tannins, steroids, flavonoids, cardiac glycosides and coumarin.

\section{Antimicrobial screening Zone of inhibition}

The antimicrobial activities of the various extracts from the plant Sesamum indicum were determined using some pathogenic microorganisms. The test microbes such as Staphylococcus aureus, Streptococcus pneumonia, Salmonella Typhi, Candida albicans, Candida krusei, Klebsiella pneumonia, Escherichia coli, Microsporan rubrum, Pseudomonas aeruginosa and Candida tropicalis were obtained from the 
Department of Medical Microbiology A.B.U. Teaching hospital, Zaria. All the isolates were checked for purity and were maintained in slants of nutrient agar for the bacteria and slant of Sabouraud dextrose agar for the fungi. Well diffusion method was the method used to determine the antimicrobial activities of the extracts from the plant. $0.1 \mathrm{~g}$ of the extract was dissolved in $10 \mathrm{ml}$ of absolute DMSO to obtain a concentration of the extracts. The active positive controls used were sparfloxacin $2 \mathrm{mg} / \mathrm{ml}$ for the bacteria and flucozole $5 \mathrm{mg} / \mathrm{ml}$ for the fungi. This was the initial concentrations used to check the antimicrobial activities of the extracts from the plant. Mueller Hinton agar and Sabouraud dextrose agar were the media used as growth media and were prepared according to the manufacturer's instructions (Oxoids of England) Cushine, (2005) and Farraro et al. (2000).

\section{Minimum inhibitory concentration}

Minimum inhibitory concentration of the extract was carried out on the microorganisms that were sensitive to the extract and was done using broth dilution method. Nutrient broth was prepared according to the manufacturer's instructions as recommended by NCCLS (National Committee for Clinical Laboratory Standards) Farraro et al. (2000). Minimum inhibition McFarland turbidity standard scale number 0.5 was prepared to give turbid solution. Normal saline was prepared and dispensed into test tube. The test microorganisms were inoculated into the normal saline and incubated at $37{ }^{\circ} \mathrm{C}$ for $6 \mathrm{hrs}$. Dilution of the microorganism in the normal saline continued until the turbidity marched that of the McFarland by visual comparison.

\section{Minimum bactericidal and fungicidal concentration}

Minimum bactericidal and fungicidal concentrations of the extracts were carried out to check whether the test microbes were killed or only their growth was inhibited. Mueller Hunton and Sabouraud dextrose agars were prepared according to the manufacturer's instruction as recommended by NCCLS (National Committee for Clinical Laboratory Standards) Farraro et al. (2000). The contents of the MIC in the serial dilution was inoculated on to the media, the media were incubated at $37{ }^{\circ} \mathrm{C}$ for 24 hours for the bacteria and at $30{ }^{\circ} \mathrm{C}$ for 1-7 days for fungi, after which the plate were observed for colonies growth. The MBC/MFC were the plate with lowest concentrations of the extract without colony growth.

\section{RESULTS AND DISCUSSION \\ Phytochemical screening of the crude leaf extracts of Sesamum indicum}

Phytochemicals are non-nutritive plant chemicals that have protective or disease preventive properties (Aggarwal et al., 2004).

The result of the phytochemical screening of the all the crude extracts of $S$. indicum carried out qualitatively as shown in Table 1 shows that the white species of the plant Sesamum indicum contains carbohydrates, reducing sugars, cardiac glycosides, saponins, steroids, triterpenes, flavonoids, and tannins. This is in agreement with Sandberg et al. (2001) that plants contain secondary metabolites which are of natural products origin. Also In vitro studies show that flavonoids also have anti-allergic, antiinflammatory, anti-microbial (Meyers, 2008), anti-cancer and anti-diarrhea activities (Coles, 2004).

However, the medicinal use of plants represents an important aspect of the history of medicine and has contributed immensely to 
the development of modern therapeutics (Akerele, 2002). Many modern day drug are derived from plants phytochemicals; example are reserpine, quinine, digoxine, morphine, codine and host of other useful drugs.

\section{Bioactivity of the crude leaf extracts of Sesamum indicum}

The anti-microbial assay of the three extracts show the various zones of inhibition of the extract against the microbes used. These results are in line with other literatures reported as regards other species of sesame, Sugano (2009) and Katsuzaki et al. (2003)

The Minimum inhibitory concentration studies showed that the petroleum spirit crude leaf extract of Sesamum indicum inhibited the growth of Staphylococcus aureus, Streptococcus pyogenes, and Candida tropicalis at a concentration of $5 \mathrm{mg} / \mathrm{ml}$ as shown in Table 3, with a corresponding $\mathrm{MBC} / \mathrm{MFC}$ at $10 \mathrm{mg} / \mathrm{ml}$ for the microorganisms with their zones of inhibition between 14-16 mm.

The Minimum inhibitory concentration studies of the crude ethylacetate leaf extract of
Sesamum indicum inhibited the growth of Staphylococcus aureus, Streptococcus pneumonia, Salmonella Typhi, Candida albicans, Candida krusei and Candida tropicalis at a concentration of $2.5 \mathrm{mg} / \mathrm{ml}$, with corresponding $\mathrm{MBC}$ at $10 \mathrm{mg} / \mathrm{ml}$ expect for Staphylococcus aureus, Streptococcus pneumonia, Salmonella Typhi, and Candida albicans in which no MBC was observed at that concentration. Their MBC were observed at the concentration of $5 \mathrm{mg} / \mathrm{ml}$ with their zones of inhibition between 24-27 mm.

The Minimum inhibitory concentration studies of the crude the methanol leaf extract of Sesamum indicum inhibited the growth of Staphylococcus aureus, Streptococcus pneumonia, Salmonella Typhi, Candida albicans, Candida krusei and Candida tropicalis at a concentration of $2.5 \mathrm{mg} / \mathrm{ml}$, with corresponding $\mathrm{MBC}$ at $10 \mathrm{mg} / \mathrm{ml}$ expect for Streptococcus pneumonia, and Candida albicans in which no MBC was observed at that concentration. Their MBCs were observed at a concentration of $5 \mathrm{mg} / \mathrm{ml}$ with their zones of inhibition between $20-27 \mathrm{~mm}$.

Table 1: Qualitative phytochemical screening of Sesamum indicum leaf extracts.

\begin{tabular}{lcccc}
\hline Constituents & $\begin{array}{c}\text { Petroleum } \\
\text { spirit extract }\end{array}$ & $\begin{array}{c}\text { Chloroform } \\
\text { extract }\end{array}$ & $\begin{array}{c}\text { Ethylacetate } \\
\text { extract }\end{array}$ & Methanol extract \\
\hline Carbohydrate & + & + & + & + \\
Saponnins & - & - & - & + \\
Flavonoids & - & - & + & + \\
Tannins & - & - & + & + \\
Cardiac glycosides & + & - & + & + \\
Steroids & - & - & + & + \\
Triterpenes & - & - & - & - \\
Anthraquinone & - & - & - & - \\
Alkaloids & - & & &
\end{tabular}

Table 2: Zone of inhibition (mm) of different crude extracts. 


\begin{tabular}{lccccc}
\hline Organisms & $\begin{array}{c}\text { PE } \\
(\mathbf{m m})\end{array}$ & $\begin{array}{c}\text { EAc } \\
(\mathbf{m m})\end{array}$ & $\begin{array}{c}\text { ME } \\
(\mathbf{m m})\end{array}$ & $\begin{array}{c}\text { Sparfloxacin } \\
(\mathbf{m m})\end{array}$ & $\begin{array}{c}\text { Fluconazole } \\
(\mathbf{m m})\end{array}$ \\
\hline Staphylococcus aureus & 16 & 27 & 24 & 42 & 0 \\
Streptococcus pyogenes & 14 & 26 & 27 & 40 & 0 \\
Cornybacterium ulcerans & 0 & 0 & 0 & 29 & 0 \\
Escherichia coli & 0 & 0 & 0 & 27 & 0 \\
Salmonellae Typhi & 0 & 25 & 20 & 32 & 0 \\
Candida albicans & 0 & 27 & 24 & 29 & 0 \\
Candida tropicalis & 14 & 24 & 20 & 0 & 41 \\
Candida krusei & 0 & 24 & 20 & 0 & 27 \\
Candida stellatoidea & 0 & 0 & 0 & 0 & 40 \\
\hline C=No
\end{tabular}

$0=$ No zone of inhibition, P.E= Petroleum spirit extract, EAc = Ethylacetate extract, M.E = Methanol extract.

Table 3: MIC and MBC/MFC result of the crude leaf extracts of $S$. indicum.

\begin{tabular}{|c|c|c|c|c|c|}
\hline \multicolumn{6}{|c|}{ MIC of crude petroleum spirit leaf extract of $S$. indicum } \\
\hline \multirow[t]{2}{*}{ Organisms } & \multicolumn{5}{|c|}{ Concentrations } \\
\hline & $\begin{array}{c}10 \\
\mathrm{mg} / \mathrm{ml}\end{array}$ & $\begin{array}{c}5 \\
\mathrm{mg} / \mathrm{ml} *\end{array}$ & $\begin{array}{c}2.5 \\
\mathrm{mg} / \mathrm{ml}\end{array}$ & $\begin{array}{c}1.25 \\
\mathrm{mg} / \mathrm{ml}\end{array}$ & $\begin{array}{c}0.625 \\
\mathrm{mg} / \mathrm{ml}\end{array}$ \\
\hline Staphylococcus aureus & - & & + & + & + \\
\hline Streptococcus pyogenes & - & & + & + & + \\
\hline Candida tropicalis & - & & + & + & + \\
\hline \multicolumn{6}{|c|}{ MBC/MFC of crude petroleum spirit leaf extract of $S$. indicum } \\
\hline \multirow[t]{2}{*}{ Organisms } & \multicolumn{5}{|c|}{ Concentrations } \\
\hline & $10 \mathrm{mg} / \mathrm{ml} *$ & $5 \mathrm{mg} / \mathrm{ml}$ & $\begin{array}{c}2.5 \\
\mathrm{mg} / \mathrm{ml}\end{array}$ & $1.25 \mathrm{mg} / \mathrm{ml}$ & $0.65 \mathrm{~g} / \mathrm{ml}$ \\
\hline Staphylococcus aureus & & + & + & + & + \\
\hline Streptococcus pyogenes & & + & + & + & + \\
\hline Candida tropicalis & & + & + & + & + \\
\hline \multicolumn{6}{|c|}{ MIC of crude ethylacetate leaf extract of $S$. indicum } \\
\hline \multirow[t]{2}{*}{ Organisms } & \multicolumn{5}{|c|}{ Concentrations } \\
\hline & $\begin{array}{c}10 \\
\mathrm{mg} / \mathrm{ml}\end{array}$ & $\begin{array}{c}5 \\
\mathrm{mg} / \mathrm{ml}\end{array}$ & $\begin{array}{c}2.5 \\
\mathrm{mg} / \mathrm{ml} *\end{array}$ & $\begin{array}{c}1.25 \\
\mathrm{mg} / \mathrm{ml}\end{array}$ & $\begin{array}{c}0.65 \\
\mathrm{mg} / \mathrm{ml}\end{array}$ \\
\hline Staphylococcus aureus & - & - & & + & + \\
\hline Streptococcus pyogenes & - & - & & + & + \\
\hline Salmonellae Typhi & - & - & & + & + \\
\hline Candida albicans & - & - & & + & + \\
\hline Candida tropicalis & - & - & & + & + \\
\hline Candida krusei & - & - & & + & + \\
\hline
\end{tabular}

\begin{tabular}{|c|c|c|c|c|c|}
\hline \multicolumn{6}{|c|}{ MBC/MFC of crude ethylacetate leaf extract of $S$. indicum. } \\
\hline \multirow[t]{2}{*}{ Organisms } & \multicolumn{5}{|c|}{\begin{tabular}{|c|} 
Concentrations \\
\end{tabular}} \\
\hline & $10 \mathrm{mg} / \mathrm{ml}$ & $5 \mathrm{mg} / \mathrm{ml}$ & $\begin{array}{c}2.5 \\
\mathrm{mg} / \mathrm{ml}\end{array}$ & $1.25 \mathrm{mg} / \mathrm{ml}$ & $\begin{array}{c}0.65 \\
\mathrm{mg} / \mathrm{ml}\end{array}$ \\
\hline Staphylococcus aureus & - & $-*$ & + & + & + \\
\hline Streptococcus pyogenes & - & $-*$ & + & + & + \\
\hline Salmonella Typhi & - & $-*$ & + & + & + \\
\hline
\end{tabular}




\begin{tabular}{|c|c|c|c|c|c|}
\hline Candida albicans & - & $-*$ & + & + & + \\
\hline Candida tropicalis & $-*$ & + & + & + & + \\
\hline Candida krusei & $-*$ & + & + & + & + \\
\hline \multicolumn{6}{|c|}{ MIC of crude methanol leaf extract of $S$. indicum } \\
\hline \multirow[t]{2}{*}{ Organisms } & \multicolumn{5}{|c|}{ Concentrations } \\
\hline & $10 \mathrm{mg} / \mathrm{ml}$ & $5 \mathrm{mg} / \mathrm{ml}$ & $\begin{array}{c}2.5 \\
\mathrm{mg} / \mathrm{ml}^{*}\end{array}$ & $1.25 \mathrm{mg} / \mathrm{ml}$ & $\begin{array}{c}0.65 \\
\mathrm{mg} / \mathrm{ml}\end{array}$ \\
\hline Staphylococcus aureus & - & - & & + & + \\
\hline Streptococcus pyogenes & - & - & & + & + \\
\hline Salmonella Typhi & - & - & & + & + \\
\hline Candida albicans & - & - & & + & + \\
\hline Candida tropicalis & - & - & & + & + \\
\hline Candida krusei & - & - & & + & + \\
\hline \multicolumn{6}{|c|}{ MBC/MFC of crude methanol leaf extract of S. indicum } \\
\hline \multirow[t]{2}{*}{ Organisms } & \multicolumn{5}{|c|}{$\begin{array}{l}\text { Concentrations } \\
\end{array}$} \\
\hline & $10 \mathrm{mg} / \mathrm{ml}$ & $5 \mathrm{mg} / \mathrm{ml}$ & $2.5 \mathrm{mg} / \mathrm{ml}$ & $1.25 \mathrm{mg} / \mathrm{ml}$ & $0.65 \mathrm{mg} / \mathrm{ml}$ \\
\hline Staphylococcus aureus & $-*$ & + & + & + & + \\
\hline Streptococcus pyogenes & - & $-*$ & + & + & + \\
\hline Salmonella Typhi & $-*$ & + & + & + & + \\
\hline Candida albicans & - & $-*$ & + & + & + \\
\hline Candida tropicalis & $-*$ & + & + & + & + \\
\hline Candida krusei & $-*$ & + & + & + & + \\
\hline
\end{tabular}

\section{Conclusion}

This study illustrates that the leaf extracts of the sesame species from Benue State region could be a good source of metabolites with antimicrobial activities worthy of further investigations.

The extracts were bactericidal against the following organisms tested against; Staphylococcus aureus, Streptococcus pyogenes, Salmonella Typhi, Bacillus cereus, Escherichia coli, Corynebacterium ulcerans, Candida albicans, Candida krusei and Candida tropicalis at different MIC and MBC/MFCs.

\section{ACKNOWLEDGEMENTS}

We wish to thank the authorities of the Herbarium (Department of the Biological Sciences, ABU, Zaria) for identifying the plant species used in this study and laboratory personnel's of the department of Chemistry, $\mathrm{ABU}$, Zaria, for providing laboratory facility for conducting this research work.

\section{REFERENCES}

Adeleye AI, Onubogu CC, Ayolabi CI, Isawumi AO, Nshiogu M. 2008. Screening of crude extracts of twelve medicinal plants and "wonder-cure" concoction used in Nigeria unorthodox medicine for activity against Mycobacterium tuberculosis isolated from tuberculosis patients' sputum. Afri J Biotech., 7(18): 3182-3187.

Adjanahoun E, Ahyi MA, Ake-Assi L, Elewude JA, Dramane K, 1991. Traditional Medicine and Pharmacopoeia. Contribution to Ethnobotanical Floristic Studies in Western Nigeria. Organization of African 
Unity, Scientific Technical and Research Commission: Lagos, Nigeria; 420 .

Aggarwal BB, Takada Y, Oommen OV. 2004. From chemoprevention to chemotherapy: Common targets and common goals. Expert Opinion and Investigation on Drugs, 13: 1327-1338.

Akerele O. 2002. Medicinal Plants and primary Health Care: Agenda for Action. Fitoterapia, 59(5): 354-355.

Bruneton J. 2009. Pharmacognosy, Phytochemistry Medicinal Plants. Tec \& Doc: Paris.

Coles M. 2004. Study of medicinal plants in Gloucester village. Ph.D thesis, Department of Botany, University of Sierra Leone, Sierra Leone. pp 76-84.

Cragg GM, Newman DJ. 2001. Natural products drug discovery and development. In Drug Discovery and Traditional Chinese Medicine: Science, Regulation, and Globalization, Yuan L (ed). United Sates National Cancer Institute; 19-32.

Cushine TP, Lamb AJ. 2005. Antimicrobial Activity of flavonoids. International Journal of Antimicrobial Agent, 26(5): 343-356.

Cohen ML. 1992. Epidemiology of drug resistance: implications for a post antimicrobial era. Science, 257: 10501055.

Farnsworth NR. 1996. Biological and Phytochemical screening of plants. Journal of Pharmaceutical Science. 55(3): 225-276.

Farraro MJ, Craig WA, Dudley MN, Eliopoulos GM, Hecht DW, Reller JL, Sheldon AT, Swenson JM, Tenover FC. 2000. Performance Standards for Antimicrobial Disk Susceptibility Tests, Approved Standard M2-A7 (7th edn). National Committee for Clinical
Laboratory Standards: Wayne, PA, USA; $1-26$.

Gills LS. 1992. Ethnomedical Uses of Plants in Nigeria. Uniben Press: Edo State Nigeria; 212-435.

Grainger NB, Wichtl M. 2001. Herbal Drugs and Phytopharmaceuticals. Medpharm GmH Scientific: Stuttgart, Gemany.

Harborne JB. 1997. Phytochemical Methods: A Guide to Modern Techniques of Plant Analysis ( $1^{\text {st }}$ edn). Chapman and Hall Ltd.: London; 49-189.

Holt GA, Chandra A. 2002. Herbs in the modern healthcare environment-An overview of uses, legalities, and the role of the healthcare professional. Clin. Res. Regulatory Affairs (USA), 19: 83107.

Ibrahim K, Nwamba CO, Mann A, Inyang US. 2005. A preliminary Investigation into the antibacterial properties of Anogeissus leiocarpus and Piper guineense seeds on Staphylococcus aureus and Pseudomonas aeruginosa. Nig. J. App. Arts \& Sci (NIJAAS), 1(1): 21-24.

Katsuzaki HS, Osawa T. 2003. Sesaminol glucosides in sesame seeds. Phytochemistry Revised Edition, 35(3): 773-776.

Kliger B, Maizes VS, Schachter CM, Park T, Gaudet R, Benn R, Remen RN. 2004. Core competencies in integrative medicine for medical school curricula: A proposal. Academic Medicine, 79: 521-531.

Meyers RA. 2008. Encyclopedia of Physical Science and Technology - Alkaloids (3rd edn).

Nakanishi K. 1999. An historical perspective of natural products chemistry. InS. Ushio (Ed.), Comprehensive Natural Products Chemistry, Elsevier, 1: 23-40.

Nascimento G, Locatelli GF, Freitas PC, Silva GL. 2000. Antibacterial activity of plant 
extracts and phytochemicals on antibiotic resistant bacteria. Brazilian Journal of Microbiology, 31: 247-256.

Odumodu CU. 1992. Antinutrients content of some locally available legumes and cereals in Nigeria. Trop Geograph Med., 44(3): 260-263.

Sandberg G, Bruhn C, 2001. Plant and animal drugs of the old Chinese material medica in the therapy of pulmonary tuberculosis. Planta Medica, 4(4): 97-104.

Sugano MT, Inoue KK. 2009. Influence of sesame lignans on various lipid parameters in rats. Agricultural and Biological Chemistry, 54(10): 26692673.
Sofowora EA. 2008. Medicinal Plants and Traditional Medicine in Africa ( $1^{\text {st }}$ edn). University of Ife Press: Ife, Nigeria; 6160.

Thoison O, Sevenet T, Niemeyer HM, Russell GB. 2004. Insect antifeedant compounds from Nothofagus dombeyi and N. pumilio. Phytochemistry, 65: 2173-2176.

Trease G, Evans W. 2009. Pharmacognosy $\left(15^{\text {th }}\right.$ edn). Saunders company Ltd; 38119. 